\title{
Beneficial Oxidative Stress-Related trans-Resveratrol Effects in the Treatment and Prevention of Breast Cancer
}

\author{
Alessandra Quarta ${ }^{1}\left(\mathbb{D}\right.$, Antonio Gaballo $^{1} \mathbb{D}$, Biswajita Pradhan $^{2}$, Srimanta Patra ${ }^{3}$, Mrutyunjay Jena ${ }^{2} \mathbb{D}$ \\ and Andrea Ragusa 1,4,*(D) \\ 1 CNR Nanotec, Institute of Nanotechnology, Via Monteroni, 73100 Lecce, Italy; \\ alessandra.quarta@nanotec.cnr.it (A.Q.); antonio.gaballo@nanotec.cnr.it (A.G.) \\ 2 Post Graduate Department of Botany, Berhampur University, Bhanja Bihar, Berhampur 760007, Odisha, India; \\ pradhan.biswajita2014@gmail.com (B.P.); mj.bot@buodisha.edu.in (M.J.) \\ 3 Cancer and Cell Death Laboratory, Department of Life Science, National Institute of Technology Rourkela, \\ Rourkela 769001, Odisha, India; 518LS2007@nitrkl.ac.in \\ 4 Department of Biological and Environmental Sciences and Technologies, University of Salento, \\ Via Monteroni, 73100 Lecce, Italy \\ * Correspondence: andrea.ragusa@unisalento.it; Tel.: +39-0832-319208
}

Citation: Quarta, A.; Gaballo, A.; Pradhan, B.; Patra, S.; Jena, M.; Ragusa, A. Beneficial Oxidative Stress-Related trans-Resveratrol Effects in the Treatment and Prevention of Breast Cancer. Appl. Sci. 2021, 11, 11041. https://doi.org/ 10.3390/app112211041

Academic Editor: Bogdan Sevastre

Received: 20 September 2021

Accepted: 19 November 2021

Published: 22 November 2021

Publisher's Note: MDPI stays neutral with regard to jurisdictional claims in published maps and institutional affiliations.

Copyright: (c) 2021 by the authors. Licensee MDPI, Basel, Switzerland. This article is an open access article distributed under the terms and conditions of the Creative Commons Attribution (CC BY) license (https:/ / creativecommons.org/licenses/by/ $4.0 /)$.

\begin{abstract}
Resveratrol is one of the most investigated polyphenols for its multiple biological activities and many beneficial effects. These are mainly related to its ability to scavenge free radicals and reduce oxidative stress. Resveratrol has also been shown to have the ability to stimulate the production of antioxidant enzymes, which interact with numerous signaling pathways involved in tumor development, and to possess side effects associated with the use of chemotherapy drugs. In this review article we summarized the main discoveries about the impact resveratrol can have in helping to prevent, as well as adjuvant treating, breast cancer. A brief overview of the primary sources of resveratrol as well as some approaches for improving its bioavailability have been also discussed.
\end{abstract}

Keywords: resveratrol; reactive oxygen species; breast cancer; antioxidants; polyphenols; oxidative stress

\section{Introduction}

Polyphenols are secondary metabolites produced by plants and also found in many natural products, such as fruit and vegetables, and their derivatives, such as tea, coffee, olive oil, and wine [1-3]. Polyphenols are well known for their antioxidant properties, which confer to them health-beneficial effects [4-7]. Among them, resveratrol is probably one of the most investigated molecules. It was first described in 1940 by Michio Takaoka, a Japanese student who was investigating extracts from traditional medicinal plants and called it "resveratrol" because the molecule had been extracted from the roots of Veratrum grandiflorum (white hellebore) and presented the skeleton of resorcinol in its molecular structure [8]. The extract from this plant was exploited for treating several allergic and inflammatory diseases, among others. However, this molecule did not attract much interest until 1997, when Jang and colleagues published an article regarding its cancer chemopreventive activity [9].

Resveratrol is the common name for 3,5,4'-trihydroxy-trans-stilbene, a natural phytoalexin derived from phenylpropanoids, that is synthesized in plants under stress conditions, such as infections or UV exposure. Under UV radiation it rapidly isomerizes to the cis geometric form, but this compound, despite interesting biological activity, has been less investigated because of its lower abundance [10]. Nevertheless, the trans-cis isomerization and fluorescence are the main deactivation pathways, although dependent on the environmental conditions [11,12].

The trans-Resveratrol can be extracted in its free form or as glucoside directly from the plant but grapes are the preferred source due to the ease of extraction. Small concentrations 
of cis-resveratrol can be also present in wines despite its lack in grapes, suggesting its formation because of yeast isomerases during the fermentation process.

Similar to other polyphenols, resveratrol has multiple biological activities and many beneficial effects, such as anti-inflammatory and antioxidant properties, mainly related to its ability to scavenge free radicals, and, as such, it can also have a positive influence on the pathologies developed due or related to oxidative stress, such as cancer (Figure 1) [13,14].

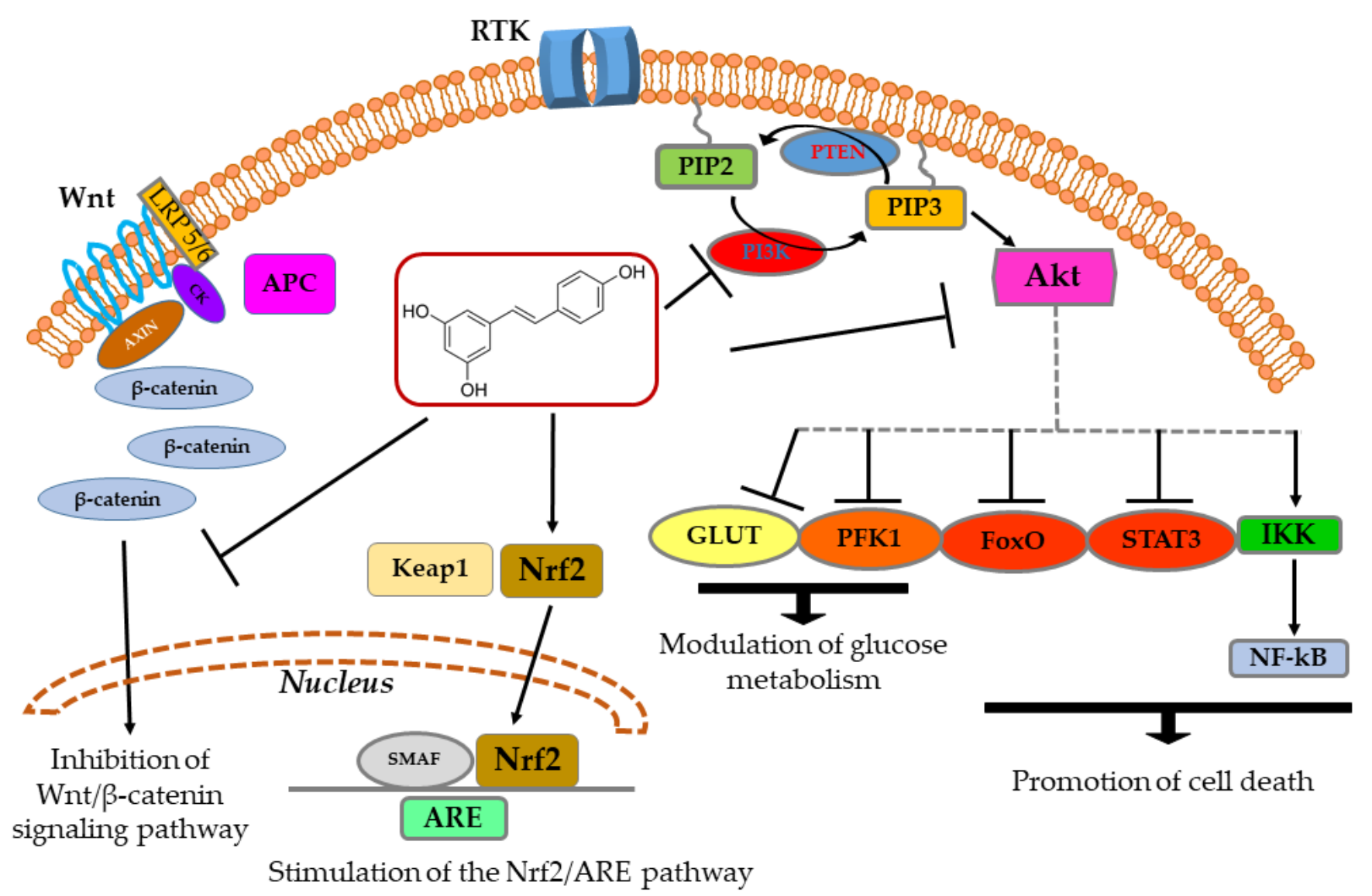

Figure 1. Chemical structure of trans-resveratrol (in the dark-red rectangle) and main biological pathways affected.

Nevertheless, some controversial results have been published in the literature, especially regarding its in vivo usefulness $[15,16]$. In fact, only a small portion of the ingested resveratrol reaches the body tissues, despite up to $70 \%$ being found in plasma, due to its quick liver metabolism, especially to glucuronide and sulfate conjugates, and excretion [17]. This limits enormously its exploitation, especially considering that the amount normally ingested (e.g., up to $5 \mathrm{mg} / \mathrm{L}$ in red wine) can reach plasma concentrations that are much lower than those tested in vitro (e.g., 30-100 $\mu \mathrm{M}$ ). However, the use of novel technological approaches could help overcome this limitation, thus improving resveratrol bioavailability [18].

In addition, this natural compound has the capacity to modulate several biochemical pathways. For example, it has been shown that treatment with resveratrol of parkin-null fibroblasts, isolated from patients with Parkinson's disease (PD), was able to increase mitochondrial biogenesis, followed by the partial rescue of mitochondrial functions and oxidative stress, through activation of the $5^{\prime}$-adenosine monophosphate-activated protein kinase (AMPK)/sirtuin 1 (SIRT1)/peroxisome proliferator-activated receptor gamma coactivator 1-alpha (PGC-1 $\alpha$ ) pathway [19]. Moreover, parkin-null primary fibroblasts are characterized by changes in the oxidative balance, and the loss of reduced glutathione (GSH) with an increase of its oxidized form (GSSG) is one of the earliest biochemical changes detectable. Resveratrol treatment of these cells contributes to preservation of 
cellular redox balance and protein homeostasis, leading to a significant increase in GSH level, reduction in GSSG/GSH ratio, and a decrease in reduced free thiol content [20].

Although free radicals are generally present inside our body, damages to cellular components, e.g., lipids, proteins, and DNA, occur when the balance between produced and scavenged radical species is impaired [21]. Several endogenous molecules, such as antioxidant enzymes (glutathione peroxidase (GPx), superoxide dismutase (SOD), catalase (CAT), glutathione reductase (GR), thioredoxin reductase (TRx), and peroxiredoxin $(\mathrm{PRx})$ ), together with food-borne exogenous antioxidant molecules (such as resveratrol and other polyphenols) help to maintain the redox homeostasis. When this homeostasis is disrupted and free radicals are in excess, they can cause lipid peroxidation, damages to cellular membranes and lipoproteins, alterations to proteins, and DNA mutations. The most representative one involves the formation of 8-hydroxyguanosine (8-OHG), which is oxidated to 8-hydroxy-2'-deoxyguanosine (8-OHdG) [22]. Similarly, 4-hydroxynonenal (4-HNE) and malonaldehyde (MDA), derived from lipid peroxidation, react with DNA, yielding etheno-DNA base adducts that compromise the correct replication process.

Uncontrolled oxidative stress can induce or help to develop several pathologies, such as cardiovascular, neurodegenerative, and respiratory diseases [23-25]. Free radicals can interact with several signaling pathways, for example, the mitogen-activated protein kinase (MAPK), signaling pathways regulating the nuclear factor kappa-light-chain-enhancer of activated B cells (NF-kB) factor, phosphatidylinositol 3-kinase (PI3K)/ Akt/mTOR (mechanistic target of rapamycin), and other transcription factors, such as the signal transducer and activator of transcription 3 (STAT3), hypoxia-inducible factor 1-alpha (HIF-1 $\alpha$ ), and p53 [26-29]. Furthermore, NF-kB and the nuclear factor erythroid 2-related factor 2 (Nrf2), which modulates the gene expression of numerous antioxidant enzymes, interplay through a range of complex molecular interactions, thus participating to balance the cellular redox status and the response to stress and inflammation [30].

Numerous studies have also demonstrated the involvement of ROS in the epithelialmesenchymal transition (EMT), characterized by the activation of mesenchymal markers, such as metalloproteases and transforming growth factor- $\beta$ (TGF- $\beta$ ), and by a simultaneous decrease in the expression levels of epithelial markers, such as E-cadherin and $\gamma$-catenin [31,32]. Finally, it has been shown that high levels of ROS modulate the angiogenesis process by interacting with numerous signal cascades, which lead to the activation of transcription factors, such as vascular endothelial growth factor (VEGF) and HIF- $1 \alpha[33,34]$. VEGF is produced by cells to stimulate the growth of new blood vessels and can induce angiogenesis by stimulating the proliferation and migration of endothelial cells.

Although high levels of ROS are implicated in oxidative DNA damage and subsequent carcinogenesis, these reactive species can also act as anti-tumorigenic agents by promoting cell death, permeabilizing the mitochondrial membrane, and inducing the release of cytochrome c into the cytosol, where it forms complexes called apoptosomes, with cytosolic proteins, such as Apaf-1. These complexes activate caspase-9, which in turn triggers effector caspases, such as caspase-3, thus initiating the apoptotic process $[35,36]$.

Breast cancer is the most common cancer type in women (30\% of female cancers in 2020), with increasing global incidence and number of deaths [37]. Several genetic and non-genetic factors, such as obesity and excessive alcohol consumption, can contribute to the development of this pathology [38]. The onset of breast cancer and its progression are classified into four molecular subtypes according to the level of expression of some molecular biomarkers, i.e., the hormonal estrogen (ERs) and progesterone (PRs) receptors, human epidermal growth factor 2 (HER2) receptor, and, although with minor relevance, the Ki-67 protein. The corresponding subtypes are the luminal A, luminal B, HER2+, and the basal-like triple-negative breast cancer (TNBC), considered to be the more metastatic and invasive one [39]. Common metastatic sites include the liver, lungs, brain, and bones. Containing tumor spreading and defining effective treatments remain the main challenges in these aggressive forms of breast cancer. 
Considering the dependence on active ER signaling for the development and progression of breast cancer, the use of selective estrogen receptor modulators (SERMs) and selective estrogen receptor degraders (SERDs), as well as chemotherapy drugs, such as cisplatin, anthracyclines, and taxanes, represents the main therapeutic approach [40]. Nevertheless, a series of antioxidant products of natural origin, including resveratrol, have aroused great interest in its prevention and potential treatment. In this review, we collected the most critical and recent shreds of evidence about the biological activity resveratrol can exert on breast cancer cells, both in vitro and in vivo, showing its potential beneficial effects in fighting this pathology.

\section{Sources and Absorption of Resveratrol}

The primary dietary sources of resveratrol include grapes, wine, apples, peanuts, and soy. Still, since the concentration of resveratrol present in all these food products is highly variable, it would be difficult to accurately estimate the average daily intake. This is related both to the fact that exogenous biological and physical stressors affect the resveratrol content in a specific food or drink and to the fact that endogenous factors interfere with the biosynthesis of resveratrol. Among the many varieties, wines made from grapes of the Pinot Noir and San Laurent showed the highest level of trans-resveratrol. Nevertheless, red wines, such as those from Salento, are rich in this natural antioxidant, along with others [41,42]. The resveratrol content is also influenced by various aspects of the wine-making process, including temperature, $\mathrm{pH}$ value, and $\mathrm{SO}_{2}$ level.

However, getting a minimal health-beneficial dose of resveratrol through wine would mean drinking several liters. For this reason, some manufacturers sell pharmaceutically manufactured supplements with exactly specified resveratrol content. Nevertheless, the clinical potential of resveratrol in humans is somewhat difficult to estimate because there is still insufficient information on the optimal dosage, biotransformation, potential side effects, and pharmacokinetic parameters. In fact, resveratrol is characterized by a reduced bioavailability linked to its ability to be rapidly metabolized and subsequently eliminated in the urine and feces [17]. The low availability of this compound is often associated with its low solubility in water $(\sim 3 \mathrm{mg} / 100 \mathrm{~mL})$ and the high permeability of the intestinal membrane. In fact, after oral administration, resveratrol is absorbed in the intestine by passive diffusion or thanks to membrane transporters. It can then be metabolized by glucuronidation and sulfation of the phenolic group (yielding resveratrol-4-O-glucuronide, resveratrol-3-O-glucuronide, and resveratrol-3-O-sulfate, respectively) or by hydrogenation of the aliphatic double bond and is subsequently released in the bloodstream, as observed in clinical trials $[43,44]$. In the bloodstream, resveratrol can bind to proteins such as albumin or to lipoproteins, such as LDL, forming complexes that dissociate when, at the cell membrane level, LDL and albumin interact with specific receptors, allowing the entry of stilbene into the cell [45]. In plasma, the concentration of unmodified free resveratrol is extremely low (around 1\% of the ingested amount) and it generally depends on the ingested dose. However, exceptionally high amounts can be associated with a number of side effects, including diarrhea, nausea, and abdominal pain.

Since one of the major obstacles related to the administration of this antioxidant compound is its bioavailability, numerous research and studies focus precisely on the improvement of the pharmacokinetic profile of resveratrol [46]. To this aim, different approaches have been proposed, such as those based on the use of emulsions and solid dispersions or on the encapsulation of resveratrol in nanocarriers, such as liposomes, micelles, and polymeric nanoparticles [47-49]. It is also possible to use a similar compound extracted from the roots of the Polygonum Cuspidatum plant, namely, polydatin, which differs from resveratrol by one molecule of glucose (Figure 2) [50,51]. The presence of the conjugated carbohydrate makes the molecule more water-soluble, increasing its bioavailability. 


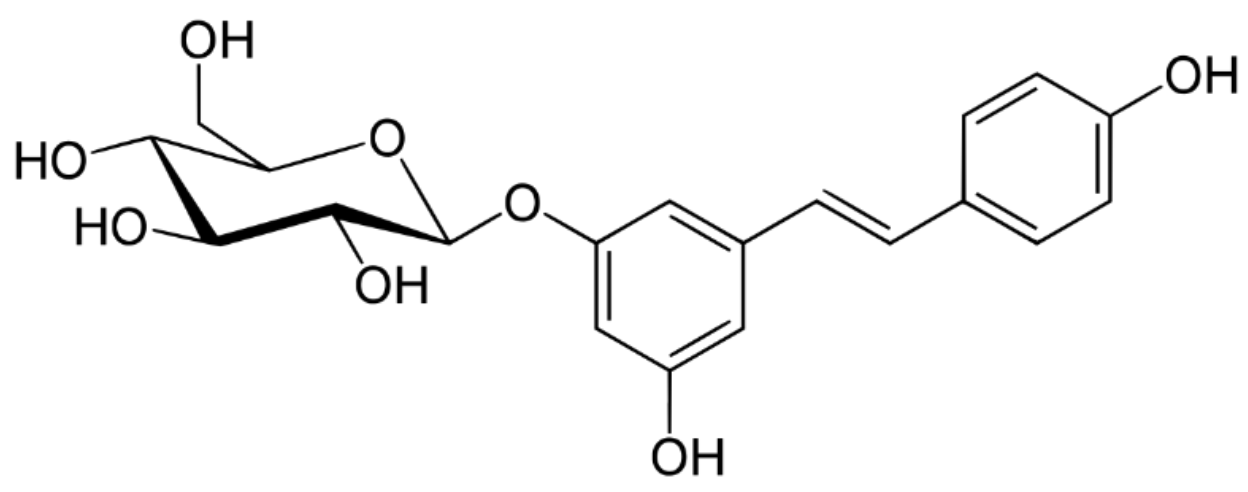

Figure 2. Chemical structure of polydatin.

Other polyphenols present in red wine, such as quercetin, catechins, and gallic acid, could also potentially function as chemopreventive agents. For example, a mixture of polyphenols extracted from vine shoots showed anti-proliferative activity superior to resveratrol alone in cancer cells due to a synergistic action between the various polyphenols [52,53]. Recently, numerous sulfonate derivatives of resveratrol were synthesized and some of them presented good antiproliferative activity in MCF-7 breast cancer cells due to their ability to inhibit aromatase, an enzyme with a key role in estrogen production and whose inhibitors have been shown to function as chemo-preventive agents in hormone-dependent breast cancers [54].

Furthermore, a substantial intake of resveratrol could interfere with the action of numerous drugs as well as, as mentioned above, with the action of CYP450 enzymes. In fact, resveratrol alters the effectiveness of some drugs, interacting precisely with the metabolism of the latter, mediated by CYPs' enzymes, such as CYP3A4, CYP2D6, and CYP2C9 [55]. Inhibition of the CYP3A4 enzyme by resveratrol causes an increase in the blood levels of drugs metabolized by this enzyme, leading to an increase in toxicity related to the drugs themselves. On the other hand, CYP2D6 converts tamoxifen into endoxifen, a powerful antiestrogen that binds to the ER, inhibiting the binding with estrogens and, therefore, the estrogen-dependent proliferation of tumor cells that express this receptor. Inhibition of this liver enzyme decreases endoxifen levels in plasma and increases the risk of relapse. Finally, the inhibition of CYP2C9, particularly abundant in the liver and intestines, by resveratrol, causes a decrease in the clearance of a wide range of drugs, increasing their toxicity. For this reason, taking supplements containing high doses of resveratrol together with drugs must be done very carefully.

\section{Resveratrol and Free Radicals}

Resveratrol can modulate a variety of biological pathways, thus influencing the cellular oxidative stress, but not only that. This molecule has attracted much interest in the last decades; nevertheless, results are sometimes discordant and further investigation is needed in order to better understand its behavior and fully exploit its potential. The main and most recent findings about resveratrol and breast cancer are summarized in Table 1 and will be discussed more in detail in the following sections.

Table 1. Direct and indirect effects of resveratrol on breast cancer.

\begin{tabular}{cccc}
\hline Direct Effect & Indirect Effect & Physiological Impact & Ref. \\
\hline $\begin{array}{c}\text { Scavenging of superoxide, hydroxyl, nitric oxide, } \\
\text { and peroxynitrate radicals }\end{array}$ & Reduction of ROS & & \\
$\begin{array}{c}\text { Non-competitive inhibition of XO } \\
\text { Blocking transcription through the AhR signaling } \\
\text { pathway }\end{array}$ & Reduction of superoxide radicals & Elimination of free radicals & [58] \\
\hline \begin{tabular}{l} 
Inhibition of CYP1A1 gene expression \\
\hline
\end{tabular} & & \\
\hline
\end{tabular}


Table 1. Cont.

\begin{tabular}{|c|c|c|c|}
\hline Direct Effect & Indirect Effect & Physiological Impact & Ref. \\
\hline $\begin{array}{l}\text { Inhibition of the dimerization of the ligand-AhR } \\
\text { complex, its binding to XRE sequences or the } \\
\text { recruitment of RNA polymerase II }\end{array}$ & & & {$[61]$} \\
\hline $\begin{array}{c}\text { Inhibition of the PKC signal transduction } \\
\text { pathway }\end{array}$ & $\begin{array}{l}\text { Inhibition of COX-2 gene } \\
\text { expression }\end{array}$ & & {$[62]$} \\
\hline Increased TGF- $\beta 1$ expression & Inhibition of 5-LOX & & [63] \\
\hline PI3K/Akt mechanism activation & Phosphorylation of Nrf2 & & {$[64,65]$} \\
\hline Activation of NQO1 & $\begin{array}{l}\text { Reduction of quinones to } \\
\text { catechols and subsequent } \\
\text { inactivation by the COMT } \\
\text { enzyme }\end{array}$ & $\begin{array}{l}\text { Stimulation of the Nrf2/ARE } \\
\text { pathway }\end{array}$ & {$[66-68]$} \\
\hline Increased concentration of PTEN & $\begin{array}{l}\text { Upregulation of CAT and } \\
\text { MnSOD mRNA levels }\end{array}$ & $\begin{array}{l}\text { Decreased concentration of } \\
\qquad \mathrm{H}_{2} \mathrm{O}_{2}\end{array}$ & {$[69,70]$} \\
\hline Suppression of Akt phosphorylation & $\begin{array}{l}\text { Inhibition of the } \\
\text { mTOR/p70S6K pathway }\end{array}$ & $\begin{array}{l}\text { PI3K survival signaling } \\
\text { pathway block }\end{array}$ & {$[71,72]$} \\
\hline Inhibition of STAT3 and NF-kB & $\begin{array}{l}\text { Inhibition of numerous } \\
\text { kinases (e.g., PKC, MAPK, } \\
\text { IKK) and some transcription } \\
\text { factors (e.g., NF-kB, STAT3, } \\
\text { HIF-1 } \alpha \text {, and AP-1) }\end{array}$ & & {$[73,74]$} \\
\hline Inhibition of IKK & $\begin{array}{l}\text { Increased expression of I-kB } \alpha \text {, } \\
\text { inactivation of NF-kB and its } \\
\text { retention in the cytoplasm }\end{array}$ & & [75] \\
\hline $\begin{array}{l}\text { Block of the activation of NF-kB induced by } \\
\text { IL- } 1 \beta \text { and TNF- } \alpha\end{array}$ & $\begin{array}{l}\text { Suppression of cell } \\
\text { proliferation, apoptosis, } \\
\text { angiogenesis, and formation } \\
\text { of metastases }\end{array}$ & $\begin{array}{l}\text { Down-regulation of cancer } \\
\text { cell proliferation }\end{array}$ & [76] \\
\hline HDAC3/p300-mediated NF-kB signaling & $\begin{array}{l}\text { Increased expression of PD-L1 } \\
\text { Enhanced binding of }\end{array}$ & & [77] \\
\hline SIRT1 activation & $\begin{array}{l}\beta \text {-catenin } / \mathrm{TCF} \text { to PD-L1 } \\
\text { promoter }\end{array}$ & & [78] \\
\hline PD-L1 glycosylation and dimerization & $\begin{array}{l}\text { Enhanced anti-tumor T-cell } \\
\text { immunity }\end{array}$ & & [79] \\
\hline Inhibition of TGF- $\beta 1$ activation & Inhibition of the EMT process & & [80] \\
\hline $\begin{array}{l}\text { Reduced expression of POLD1, VEGF, and } \\
\text { HIF- } 1 \alpha\end{array}$ & $\begin{array}{l}\text { Inhibition of anti-apoptotic } \\
\text { proteins and activation of } \\
\text { pro-apoptotic ones }\end{array}$ & Reduced angiogenesis & {$[81,82]$} \\
\hline $\begin{array}{l}\text { Phosphorylation or acetylation of p53 at the level } \\
\text { of the serine residue } 15\end{array}$ & $\begin{array}{l}\text { Increased expression of } \\
\text { pro-apoptotic proteins; } \\
\text { activation of effector caspases } \\
\text { and decreased expression of } \\
\text { anti-apoptotic proteins }\end{array}$ & $\begin{array}{l}\text { Induced arrest of the cell cycle } \\
\text { at the level of the G0/G1 and } \\
\text { S phase }\end{array}$ & {$[83,84]$} \\
\hline $\begin{array}{c}\text { Phosphorylation of mTOR targets 4EBP1 and } \\
\text { P70S6K }\end{array}$ & $\begin{array}{l}\text { Reduction of cancer cells' } \\
\text { basal autophagy used to } \\
\text { counteract their basal stress }\end{array}$ & Increased ROS production & [85] \\
\hline $\begin{array}{l}\text { Inhibition of PI3K/Akt-mediated } \\
\text { phosphorylation }\end{array}$ & $\begin{array}{l}\text { Decreased phosphorylated } \\
\text { levels of FoxO }\end{array}$ & $\begin{array}{l}\text { Overexpression of } \\
\text { pro-apoptotic proteins and } \\
\text { downregulation of the } \\
\text { anti-apoptotic ones }\end{array}$ & {$[86]$} \\
\hline \multirow{2}{*}{$\begin{array}{c}\text { Increased SIRT1 expression and decreased } \\
\beta \text {-catenin expression } \\
\text { Deacetylation of the p65 subunit of the NF-kB } \\
\text { complex }\end{array}$} & \multirow[t]{2}{*}{$\begin{array}{l}\text { Reduction of the EMT } \\
\text { processes }\end{array}$} & $\begin{array}{l}\text { Inhibited proliferation and } \\
\text { migration of cancer cells }\end{array}$ & [87] \\
\hline & & Promotion of cell death & {$[88,89]$} \\
\hline Increased FoxO & Increased SOD & Reduced oxidative stress & [90] \\
\hline
\end{tabular}


Table 1. Cont.

\begin{tabular}{|c|c|c|c|}
\hline Direct Effect & Indirect Effect & Physiological Impact & Ref. \\
\hline Inhibition of the activity of PFK & $\begin{array}{l}\text { Decreased glucose uptake and } \\
\text { glycolytic metabolism }\end{array}$ & $\begin{array}{l}\text { Modulation of glucose } \\
\text { metabolism }\end{array}$ & {$[91,92]$} \\
\hline $\begin{array}{c}\text { Interaction with membrane-bound ERs } \\
\text { Inhibition of steroidogenesis and estrogen } \\
\text { biosynthesis }\end{array}$ & $\begin{array}{l}\text { Modulation of genomic and } \\
\text { non-genomic activities }\end{array}$ & $\begin{array}{l}\text { Modulation of steroidal } \\
\text { pathways }\end{array}$ & [93] \\
\hline $\begin{array}{l}\text { Reduction of CYP1B1 activity and, thus, the } \\
\text { formation of } 4-\mathrm{OHE}_{1}\left(\mathrm{E}_{2}\right)\end{array}$ & $\begin{array}{l}\text { Prevention of the formation of } \\
\text { estrogen-DNA adducts }\end{array}$ & $\begin{array}{l}\text { Potential inhibition of cancer } \\
\text { initiation }\end{array}$ & [94] \\
\hline AMPK activation & \multirow{2}{*}{$\begin{array}{l}\text { Increased SOD, CAT, and } \\
\text { GSH levels; reduced } \\
\text { myeloperoxidase levels } \\
\text { Inhibition of p38MAPK and } \\
\text { caspases; activation of } \\
\text { cytoprotective autophagy }\end{array}$} & \multirow[b]{2}{*}{ Reduced DOX cardiotoxicity } & [95] \\
\hline SIRT1 activation & & & {$[96,97]$} \\
\hline Modulation of PI3K/Akt and NF-kB expressions & $\begin{array}{l}\text { Inhibition of cell invasion and } \\
\text { migration through EMT }\end{array}$ & $\begin{array}{l}\text { Enhanced anti-tumor effect } \\
\text { and reduced side effects of } \\
\text { cisplatin }\end{array}$ & [98] \\
\hline $\begin{array}{l}\text { Significant decrease in the activity of antioxidant } \\
\text { enzymes }\end{array}$ & Increased ROS generation & $\begin{array}{l}\text { Increased apoptotic effect of } \\
\text { ionizing radiation treatment }\end{array}$ & [99] \\
\hline
\end{tabular}

The antioxidant activity of resveratrol is linked to its ability to eliminate reactive oxygen species (ROS), especially superoxide $\left(\bullet \mathrm{O}^{2-}\right)$, hydroxyl $(\mathrm{OH} \bullet)$, nitric oxide $(\mathrm{NO})$, and peroxynitrite $\left(\mathrm{ONOO}^{-}\right)$radicals and all those radicals produced in metal-catalyzed reactions, such as the Fenton reaction $[56,57]$. In addition, resveratrol has the ability to inhibit xanthine oxidase $(\mathrm{XO})$, which is also responsible for the generation of superoxide radicals, through a non-competitive allosteric binding [58]. Furthermore, resveratrol exhibits protective effects against lipid peroxidation and oxidative damage to DNA resulting from the accumulation of ROS. It can also block the transcriptional activation of cytochrome P450 enzymes (such as CYP1A1, CYP1B1, and CYP1A2), i.e., phase I enzymes that convert xenobiotics into toxic quinones that can generate $\bullet \mathrm{O}^{2-}$ and that are also involved in the metabolism of estrogens and in the formation of DNA adducts, as well as the metabolism of numerous drugs. The inhibition of CYP1A1 gene expression by resveratrol occurs by blocking transcription through the aryl hydrocarbon receptor (AhR) signaling pathway $[59,60]$. The expression of the CYAP1A1 gene is induced by the binding of a ligand, such as benzo $(\alpha)$ pyrene or 2,3,7,8-tetrachlorodibenzo- $p$-dioxin (TCDD), to the AhR receptor. The ligand-AhR complex undergoes dimerization with the AhR nuclear translocator nuclear protein (ARNT) and it is then translocated to the nucleus, where it binds to specific regions of DNA called xenobiotic responsive elements (XRE), which are located upstream of the site of initiation of transcription of the genes coding for enzymes that metabolize xenobiotics. Resveratrol has the ability to act on this process by inhibiting the dimerization of the complex or by inhibiting its binding to XRE sequences or the recruitment of RNA polymerase II, which is vital for the transcription of the CYP1A1 gene [61].

Other activities related to this natural compound are the inhibition of the protein kinase C (PKC) signal transduction pathway, thus suppressing the activation of inducible cyclooxygenases (COX-2), also responsible for the production of ROS, mediated by phorbol esters (e.g., phorbol-12-myristate-13-acetate, PMA) in the cells of the mammary epithelium [62]. In addition, resveratrol increases the expression of TGF- $\beta 1$, thus mediating the inhibition of 5-lipoxygenase (5-LOX) in a concentration-dependent manner, and of other phase II enzymes that contribute to the detoxification processes, activating the Nrf2antioxidant responsive element (ARE) pathway $[63,100]$. 


\subsection{Resveratrol and the Nrf2/ARE Pathway}

Nrf2 is formed by six Nrf2-ECH homology (Neh) domains and it is one of the most significant regulators of the antioxidant response. Generally, Nrf2 is bound to Kelch-like ECH-associated protein 1 (Keap1) through the Neh2 domain, which is also a substrate for ubiquitin E3 ligase that promotes proteasome-mediated degradation of Nrf2. Under conditions of oxidative stress, the oxidation of Keap1 induces a conformational change that causes the subsequent detachment of Nrf2 and its translocation to the nucleus, where it binds AREs. Formation of the Nrf2-ARE complex then promotes the expression of genes that code for antioxidant and phase II detoxifying enzymes, such as GPx, heme-oxygenase 1 (HO-1), SOD, CAT, and NADPH dehydrogenase quinone 1 (NQO1).

Resveratrol promotes the production of these enzymes by stimulating Nrf2 phosphorylation through a PI3K/Akt-dependent mechanism, thus causing the release of Nrf2 from Keap1 and its subsequent translocation into the nucleus [64,65]. Generally, NQO1 activation plays a significant role in preventing breast cancer [66-68,101]. In particular, estrogens are metabolized by CYP1A1 and CYP1B1 to catechols, whose oxidation products are responsible for the formation of DNA adducts [102]. The induction of NQO1 stimulated by resveratrol facilitates the reduction of quinones to catechols and their subsequent inactivation by the catechol-O-methyltransferase (COMT) enzyme (Figure 3).

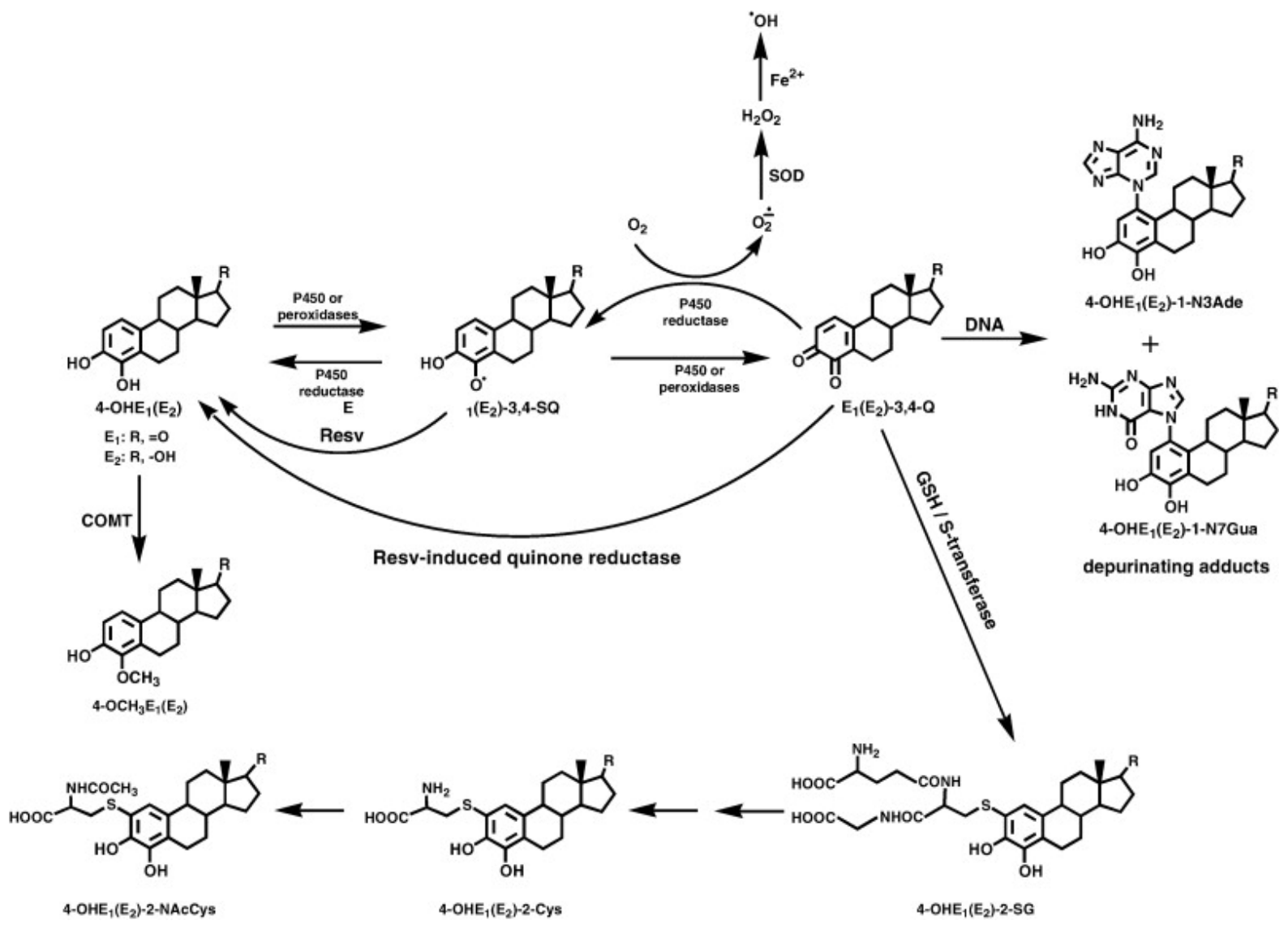

Figure 3. Mechanisms by which resveratrol can prevent estrogen-initiated breast cancer (with permission from [68]).

Quinones formed by the estrogens' metabolism can also be detoxified through conjugation with glutathione (GSH) by the glutathione-S-transferase (GST) enzyme [103].

The most common estrogen present in the breast is $17 \beta$-estradiol $\left(E_{2}\right)$. This hormone is hydroxylated to catechol-estrogens, such as 2- and 4-hydroxyestradiol $\left(2-\mathrm{OHE}_{2}\right.$ and $4-\mathrm{OHE}_{2}$, respectively). The catechol-estrogens are then methylated by the COMT enzyme, forming 2-methoxy- $\mathrm{E}_{2}$ and 4-methoxy- $\mathrm{E}_{2}$, respectively [104]. 


\subsection{Resveratrol and PTEN in the PI3K/Akt/mTOR Signaling Pathway}

The PI3K/Akt/mTOR signaling pathway is a crucial intracellular pathway in cell cycle regulation directly related to cell proliferation and apoptosis, as well as to diseases such as cancer. It also plays a critical role in breast cancer, where growth factors and hormones, such as the HER and estrogen, respectively, activate this signaling cascade [105]. Indeed, upon binding of the growth factor, the associated receptor tyrosine kinase (RTK) activates the PI3K heterodimer [106]. This kinase promotes the phosphorylation of several substrates, including phosphatidylinositol-4,5-bisphosphate (PIP2), which is then converted into phosphatidylinositol-3,4,5 triphosphate (PIP3). The PIP3 activates Akt, which, in turn, can phosphorylate numerous molecules, producing as a final effect the induction of cell growth and resistance to apoptosis [107]. The phosphatase and tensin homolog protein (PTEN) is a phosphatase capable of dephosphorylating PIP3 and acting as a tumor suppressor, negatively modulating the PI3K/Akt signaling pathway [108].

The mTOR is a serine/threonine protein kinase located downstream of PI3K and Akt. Two distinct protein complexes, mTORC1 and mTORC2, coexist: $\mathrm{mTORC} 1$ is activated by Akt, while mTORC2 directly activates Akt by phosphorylation. Both complexes promote cell growth and proliferation [109]. The involvement of the PI3K/Akt/mTOR signaling pathway in tumor progression has been known for many years; therefore, it is not surprising that it represents a major therapeutic target, also in breast cancer, through the development and testing of PI3K and mTOR inhibitors [110].

Resveratrol also targets this pathway. In fact, it regulates the expression of antioxidant enzymes through mechanisms involving the PI3K/Akt signaling pathway, increasing the levels of PTEN, which antagonizes the activity of PI3K and, consequently, its ability to phosphorylate protein substrates, including Akt [69]. Unexpectedly, the increase in PTEN proved to be associated with increased mRNA levels related to antioxidant enzymes such as CAT, GPx, and MnSOD, promoting their activity and decreasing the concentration of free radicals, particularly hydrogen peroxide [70].

Furthermore, resveratrol demonstrates an inhibitory effect on the activation of the mTOR/p70S6K pathway, likely by suppressing Akt signaling [71], and on the TOR/ULK1 pathway, thus leading to autophagy in breast cancer cells [72].

\subsection{Effect of Resveratrol on Other Carcinogenic Pathways}

The antioxidant properties of resveratrol also include the regulation of numerous signaling pathways involved in the carcinogenesis process. This compound inhibits numerous kinases, such as PKC, MAPK, and IKK (IkB kinase), and some transcription factors, such as NF-kB, STAT3, HIF- $1 \alpha$, and AP-1 (Activator Protein-1), often activated by ROS, such as $\mathrm{H}_{2} \mathrm{O}_{2}[73,74]$.

As mentioned above, the inflammatory process contributes to the development and progression of carcinogenesis. An essential mediator of the tumor transformation induced by inflammation is the nuclear transcription factor NF-kB, a heterodimer consisting of two subunits, p65 and p50. Under normal conditions, NF-kB is bound to an inhibitor of $\mathrm{kB}(\mathrm{I}-\mathrm{kB})$ in the cytoplasm. ROS accumulation mediates the phosphorylation of I-kB by a kinase (i.e., the IKK, inhibitor of NF-kB kinase), leading to its ubiquitination and degradation in the proteasome. This process facilitates the transfer of NF-kB into the nucleus, inside which it modulates the expression of genes related to the inflammatory response. The antioxidant and anti-cancer effects of resveratrol can be attributed to the inhibition of IKK and, consequently, an increase in the expression of I- $-\mathrm{BB} \alpha$, the inactivation of NF-kB, and the latter's retention in the cytoplasm, inhibiting its translocation into the nucleus. Resveratrol can also block NF-kB activation induced by inflammatory mediators, such as IL- $1 \beta$ and tumor necrosis factor- $\alpha$ (TNF- $\alpha$ ), with the subsequent suppression of cell proliferation, apoptosis, and angiogenesis and formation of metastases [75,76].

Resveratrol also increases the expression level of programmed cell death ligand 1 (PD-L1), a modulator of the immune system whose blockade already proved to be a valid therapy for solid tumors, via HDAC3/p300-mediated NF-kB signaling [77]. Upregula- 
tion of PD-L1 was shown to be dose dependent in lung cancer cells and suppression of $\mathrm{T}$ cell function was already observed at relatively low-pharmacologically achievableresveratrol concentrations [78]. The Wnt pathway proved to be critical for mediating the resveratrol-induced PD-L1 upregulation and, in particular, resveratrol activated SIRT1, which promoted Snail protein deacetylation, which, in turn, inhibited transcription of Axin2, thus leading to disassembly of destruction complex and enhanced binding of $\beta$-catenin/TCF to PD-L1 promoter. By combining biochemical, computational, and microscopy approaches, it was shown that resveratrol can directly target PD-L1 glycosylation and dimerization, thus interfering with the protein's stability and trafficking, ultimately impeding its targeting to the cancer cell plasma membrane and enhancing anti-tumor T-cell immunity [79].

In addition to modulating NF-kB expression to inhibit cancer progression, resveratrol can also inhibit the EMT induced by TGF- $\beta 1$. This cytokine is involved in the regulation of EMT through Smad-dependent signaling pathways. Smad2 and Smad3 proteins, particularly their TGF- $\beta 1$-regulated overexpression and phosphorylation, play a key role in the EMT transition of breast cancer. Resveratrol decreases the levels of these proteins by inhibiting their phosphorylation and, consequently, the EMT process responsible for the formation of metastases [80].

Resveratrol can also reduce angiogenesis by lowering the expression of VEGF and HIF$1 \alpha$ and induce cell death by inhibiting anti-apoptotic proteins, such as proteins belonging to the Bcl-2 family, and activating pro-apoptotic proteins, such as Bad, Bax, and Bak [81]. All these mechanisms are related to the activation of the p53 oncosuppressor, a transcription factor involved in cell cycle regulation and apoptosis [111]. This was recently confirmed by Liang and colleagues, who demonstrated through RNA sequencing that genes affected by resveratrol treatment in MDA-MB-231 cells were mainly involved in apoptosis and the p53 signaling pathway [82].

Resveratrol can induce cancer cell death through the intrinsic apoptotic pathway, which is mediated by the formation of apoptosomes and the release of apoptogenic factors, such as cytochrome $c$ and caspase 2/9 from the mitochondrial intermembrane space, or through the extrinsic apoptotic pathway involving the superfamily of TNF receptors, such as Fas (CD95 or APO-1) or TRAIL receptors (TNF-Related Apoptosis-Inducing Ligand). Resveratrol induces the arrest of the cell cycle at the level of the G0/G1 and S phase through the phosphorylation or acetylation of p53 at the level of the serine residue 15, thanks to the activation of MAPK, inducing an increase in the expression of pro-apoptotic proteins, activation of effector caspases, such as caspase $8 / 9$, and a decrease in the expression of antiapoptotic proteins, such as Bcl-2 [83,84]. Recently, Arena and co-workers explored more in detail the mechanism underlying the anticancer effect of resveratrol in both Her2/neupositive breast and salivary cancer cell lines. It has been shown that the cytotoxic effect of resveratrol in these cell models is essentially related to the increase of phosphorylation of mTOR targets 4EBP1 and P70S6K, to a reduction of the basal autophagy, which cancer cells use to counteract their basal stress, and, finally, also to an increase of ROS production known to be detrimental for cancer cell survival [85].

Resveratrol also influences the activity of transcription factors known as FoxO (Forkhead box $\mathrm{O}$ ), involved in numerous cellular processes, such as cell cycle progression, apoptosis, and the response to oxidative stress. In various types of cancer, the transcriptional activity of FoxO is inhibited due to phosphorylation mediated by constitutive activation of the PI3K/Akt pathway [112]. FoxO phosphorylation facilitates the interaction with 14-3-3 proteins and subsequent nuclear export. In this regard, resveratrol inhibits PI3K/Akt-mediated phosphorylation and consequently causes a decrease in phosphorylated FoxO levels. It also promotes nuclear translocation, an increase in DNA binding affinity, and, finally, the transcriptional activity of FoxO, which plays a significant role in the apoptotic process, being involved in the overexpression of pro-apoptotic proteins and downregulating the anti-apoptotic ones, finally inducing cell death [86]. 
Resveratrol also activates the action of SIRT1, which plays a dual role in cancer progression and suppression, by modulating the SIRT1/ $\beta$-catenin signaling pathway and thus reversing EMT in tumor cells [87]. Furthermore, the activation and overexpression of SIRT1 is involved in the apoptotic process through the deacetylation of p53 or other proteins that act as tumor suppressors or transcription factors, such as FoxO and NF-kB [88]. In fact, the activation of SIRT1 by resveratrol involves the deacetylation of the p65 subunit of the NF-kB complex, thus promoting cell death [89]. The activation of SIRT1 by resveratrol also induces an increase in the expression of SOD, mediated by the FoxO transcription factor [90].

Finally, it is worth mentioning the role of resveratrol as a modulator of the tumor glucose metabolism. Compared to healthy tissues, tumor cells uptake and consume high amounts of glucose to meet their high energy demand. Their glycolytic metabolism is characterized by a large production of lactate, even in aerobic conditions (the so-called Warburg effect) [113]. Resveratrol has been reported to interfere with this metabolism in breast cancer by decreasing glucose uptake, mediated by the Glut1 transporter, and inhibiting the activity of 6-phosphofructo-1-kinase (PFK), one of the enzymes of the glycolytic metabolism, thus leading to a reduction in cell proliferation and viability [91,92].

Resveratrol has also an effect on steroidal pathways by interacting with membranebound ERs and modulating its genomic and non-genomic activities, as well as by inhibiting steroidogenesis and estrogen biosynthesis at multiple steps along the pathway [93]. In addition, resveratrol is also able to prevent the formation of estrogen-DNA adducts, thus potentially inhibiting cancer initiation [94].

\subsection{Other Effects}

Resveratrol is also used as a chemoprotective agent against the toxic effects caused by numerous chemotherapy drugs, such as anthracyclines and, in particular, doxorubicin (DOX). DOX, one of the most important antineoplastic agents against breast cancer, can intercalate in the DNA double helix, thus inhibiting the activity of DNA and RNA polymerase. However, the use of this anticancer drug involves several undesirable effects, including oxidative stress, especially at the heart tissue level, by increasing ROS production, lipid peroxidation, and reduction of endogenous antioxidants [95]. For this reason, DOX and some of its alcoholic metabolites (DOXol) are responsible for chronic cardiotoxicity. It has been verified that the co-administration of natural antioxidants, such as resveratrol, lowers the ROS levels and, at the same time, increases the expression of some antioxidant enzymes, such as SOD and CAT [96]. Furthermore, ROS generated by doxorubicin treatment can cause a release of $\mathrm{Ca}^{2+}$ ions from the sarcoplasmic reticulum, leading to an increase in the intracellular calcium levels. This leads to an increased uptake of calcium in the mitochondria that induce the release of cytochrome $\mathrm{c}$ in the cytosol, i.e., a promotion of the apoptotic process of cardiomyocytes.

In addition, DNA damage, linked directly to the action of DOX or indirectly to the action of the ROS generated by it, results in an increase in the expression and activation of p53, which overexpresses genes related to pro-apoptotic proteins, such as Bax. Resveratrol limits the apoptotic effect of DOX by activating SIRT1, which reduces the cell death process by inhibiting the activation of p38MAPK and the activation of caspases, or by inducing cytoprotective autophagy, a cellular process of removal and degradation of damaged cytoplasmic components (including ROS) by acting on the PI3K/Akt/mTOR/AMPK pathway $[97,98]$. Resveratrol is able to activate AMPK, which inhibits mTORC1, thus promoting autophagy.

Resveratrol was also delivered in conjunction with tamoxifen, a non-steroidal estrogen antagonist in ER+ breast cancer therapeutics, through layer-by-layer nanoparticles, which showed potent cytotoxicity and enhanced apoptosis in both MCF-7 and CAL-51 human breast cancer cell lines by increasing the expression of p53 and caspase-8 [114].

Resveratrol also increases the effectiveness of some chemotherapy drugs, such as cisplatin, sensitizing the cancer cells towards apoptosis in a synergistic way, also reducing 
the side effects of the chemotherapeutic [115]. This effect is probably induced by a reduced expression of TGF- $\beta 1$ and an increased expression of E-cadherin, inhibiting cell invasion and migration through EMT. Thanks to its multiple effects and therapeutic potential in cancer, it is being evaluated as an adjuvant drug or dietary supplement in several clinical trials. Furthermore, it has been shown that resveratrol significantly increased the apoptotic effect of ionizing radiation treatment in the MCF-7 breast cancer cell line, most likely by increasing ROS generation with involvement of intrinsic or extrinsic apoptotic pathways [99].

\section{Conclusions}

Resveratrol, a polyphenolic compound that plants produce to protect themselves in abiotic and biotic stressful situations, such as injuries, infections by fungi or bacteria, and exposure to ultraviolet rays, also exhibits a variety of beneficial effects for the human being. This compound has been extensively studied for its antioxidant potential for preventing and treating numerous diseases, including breast cancer. It has been shown that resveratrol can scavenge ROS and thus reduce oxidative stress, restoring the body's antioxidant-oxidant homeostatic levels. Resveratrol has been also shown to have the ability to stimulate the production of antioxidant enzymes, to interact with numerous signaling pathways involved in tumor development often altered by an excess of free radicals, and to demonstrate the side effects associated with the use of chemotherapy drugs. The main limitation of this compound is its bioavailability, but the advent of novel drug delivery systems can overcome this limit. In conclusion, although there is still a lot to discover about this compound, especially regarding its in vivo behavior, resveratrol could represent an excellent approach to prevent and help fight, synergistically with appropriate anticancer drugs, breast cancer.

Author Contributions: Conceptualization, A.R.; resources, A.Q. and A.R.; writing-original draft preparation, A.R.; writing—review and editing, A.Q., A.G., B.P., S.P., M.J. and A.R.; visualization, A.Q. and A.R.; supervision, A.R.; project administration, A.R.; funding acquisition, A.R. All authors have read and agreed to the published version of the manuscript.

Funding: This research received no external funding.

Acknowledgments: The authors would like to acknowledge the support of the following Italian projects: "Tecnopolo per la medicina di precisione" (TecnoMed Puglia)—Regione Puglia: DGR n. 2117 del 21 November 2018 (CUP: B84I18000540002).

Conflicts of Interest: The authors declare no conflict of interest.

\section{References}

1. Ragusa, A.; Centonze, C.; Grasso, M.E.; Latronico, M.F.; Mastrangelo, P.F.; Fanizzi, F.P.; Maffia, M. Composition and Statistical Analysis of Biophenols in Apulian Italian EVOOs. Foods 2017, 6, 90. [CrossRef] [PubMed]

2. Gutiérrez-Escobar, R.; Aliaño-González, M.J.; Cantos-Villar, E. Wine Polyphenol Content and Its Influence on Wine Quality and Properties: A Review. Molecules 2021, 26, 718. [CrossRef] [PubMed]

3. Khan, J.; Deb, P.K.; Priya, S.; Medina, K.D.; Devi, R.; Walode, S.G.; Rudrapal, M. Dietary Flavonoids: Cardioprotective Potential with Antioxidant Effects and Their Pharmacokinetic, Toxicological and Therapeutic Concerns. Molecules 2021, 26, 4021. [CrossRef] [PubMed]

4. Fraga, C.G.; Croft, K.D.; Kennedy, D.O.; Tomás-Barberán, F.A. The effects of polyphenols and other bioactives on human health. Food Funct. 2019, 10, 514-528. [CrossRef] [PubMed]

5. Pradhan, B.; Nayak, R.; Patra, S.; Jit, B.P.; Ragusa, A.; Jena, M. Bioactive Metabolites from Marine Algae as Potent Pharmacophores against Oxidative Stress-Associated Human Diseases: A Comprehensive Review. Molecules 2020, 26, 37. [CrossRef]

6. Mallamaci, R.; Budriesi, R.; Clodoveo, M.L.; Biotti, G.; Micucci, M.; Ragusa, A.; Curci, F.; Muraglia, M.; Corbo, F.; Franchini, C. Olive Tree in Circular Economy as a Source of Secondary Metabolites Active for Human and Animal Health Beyond Oxidative Stress and Inflammation. Molecules 2021, 26, 1072. [CrossRef] [PubMed]

7. Pradhan, B.; Patra, S.; Behera, C.; Nayak, R.; Jit, B.P.; Ragusa, A.; Jena, M. Preliminary Investigation of the Antioxidant, Anti-Diabetic, and Anti-Inflammatory Activity of Enteromorpha intestinalis Extracts. Molecules 2021, 26, 1171. [CrossRef]

8. Takaoka, M.J. Of the phenolic substances of white hellebore (Veratrum grandiflorum Loes. fil.). J. Faculty Sci. Hokkaido Imperial Univ. 1940, 3, 1-16. 
9. Jang, M.; Cai, L.; Udeani, G.O.; Slowing, K.V.; Thomas, C.F.; Beecher, C.W.; Fong, H.H.; Farnsworth, N.R.; Kinghorn, A.D.; Mehta, R.G.; et al. Cancer chemopreventive activity of resveratrol, a natural product derived from grapes. Science 1997, 275, 218-220. [CrossRef]

10. Orallo, F. Comparative studies of the antioxidant effects of cis- and trans-resveratrol. Curr. Med. Chem. 2006, 13, 87-98. [CrossRef] [PubMed]

11. Allen, M.T.; Whitten, D.G. The photophysics and photochemistry of .alpha.,.omega.-diphenylpolyene singlet states. Chem. Rev. 1989, 89, 1691-1702. [CrossRef]

12. Tosato, M.G.; Vicendo, P.; Thomas, A.H.; Lorente, C. Clearing up the photochemistry of resveratrol: Effect of the solvent. J. Photochem. Photobiol. A Chem. 2018, 367, 327-331. [CrossRef]

13. Graf, B.A.; Milbury, P.E.; Blumberg, J.B. Flavonols, flavones, flavanones, and human health: Epidemiological evidence. J. Med. Food 2005, 8, 281-290. [CrossRef] [PubMed]

14. Salehi, B.; Mishra, A.P.; Nigam, M.; Sener, B.; Kilic, M.; Sharifi-Rad, M.; Fokou, P.V.T.; Martins, N.; Sharifi-Rad, J. Resveratrol: A Double-Edged Sword in Health Benefits. Biomedicines 2018, 6, 91. [CrossRef]

15. Andreani, C.; Bartolacci, C.; Wijnant, K.; Crinelli, R.; Bianchi, M.; Magnani, M.; Hysi, A.; Iezzi, M.; Amici, A.; Marchini, C. Resveratrol fuels HER2 and ER $\alpha$-positive breast cancer behaving as proteasome inhibitor. Aging 2017, 9, 508-523. [CrossRef] [PubMed]

16. Gianchecchi, E.; Fierabracci, A. Insights on the Effects of Resveratrol and Some of Its Derivatives in Cancer and Autoimmunity: A Molecule with a Dual Activity. Antioxidants 2020, 9, 91. [CrossRef] [PubMed]

17. Walle, T.; Hsieh, F.; DeLegge, M.H.; Oatis, J.E., Jr.; Walle, U.K. High absorption but very low bioavailability of oral resveratrol in humans. Drug Metab. Dispos. 2004, 32, 1377-1382. [CrossRef] [PubMed]

18. Machado, N.D.; Fernández, M.A.; Díaz, D.D. Recent Strategies in Resveratrol Delivery Systems. ChemPlusChem 2019, 84, 951-973. [CrossRef] [PubMed]

19. Ferretta, A.; Gaballo, A.; Tanzarella, P.; Piccoli, C.; Capitanio, N.; Nico, B.; Annese, T.; Di Paola, M.; Dell'aquila, C.; De Mari, M.; et al. Effect of resveratrol on mitochondrial function: Implications in parkin-associated familiar Parkinson's disease. Biochim. Biophys. Acta 2014, 1842, 902-915. [CrossRef]

20. Vergara, D.; Gaballo, A.; Signorile, A.; Ferretta, A.; Tanzarella, P.; Pacelli, C.; Di Paola, M.; Cocco, T.; Maffia, M. Resveratrol Modulation of Protein Expression in parkin-Mutant Human Skin Fibroblasts: A Proteomic Approach. Oxid. Med. Cell. Longev. 2017, 2017, 2198243. [CrossRef]

21. Valko, M.; Izakovic, M.; Mazur, M.; Rhodes, C.J.; Telser, J. Role of oxygen radicals in DNA damage and cancer incidence. Mol. Cell. Biochem. 2004, 266, 37-56. [CrossRef] [PubMed]

22. Valavanidis, A.; Vlachogianni, T.; Fiotakis, C. 8-hydroxy-2'-deoxyguanosine (8-OHdG): A critical biomarker of oxidative stress and carcinogenesis. J. Environ. Sci. Health C Environ. Carcinog. Ecotoxicol. Rev. 2009, 27, 120-139. [CrossRef] [PubMed]

23. Hayes, J.D.; Dinkova-Kostova, A.T.; Tew, K.D. Oxidative Stress in Cancer. Cancer Cell. 2020, 38, 167-197. [CrossRef]

24. Essick, E.E.; Sam, F. Oxidative stress and autophagy in cardiac disease, neurological disorders, aging and cancer. Oxid. Med. Cell. Longev. 2010, 3, 168-177. [CrossRef] [PubMed]

25. Kiyokawa, H.; Hoshino, Y.; Sakaguchi, K.; Muro, S.; Yodoi, J. Redox Regulation in Aging Lungs and Therapeutic Implications of Antioxidants in COPD. Antioxidants 2021, 10, 1429. [CrossRef] [PubMed]

26. Gloire, G.; Legrand-Poels, S.; Piette, J. NF-kappaB activation by reactive oxygen species: Fifteen years later. Biochem. Pharmacol. 2006, 72, 1493-1505. [CrossRef] [PubMed]

27. Simon, A.R.; Rai, U.; Fanburg, B.L.; Cochran, B.H. Activation of the JAK-STAT pathway by reactive oxygen species. Am. J. Physiol. 1998, 275, 1640-1652. [CrossRef] [PubMed]

28. Görlach, A.; Kietzmann, T. Superoxide and derived reactive oxygen species in the regulation of hypoxia-inducible factors. Methods Enzymol. 2007, 435, 421-446. [CrossRef]

29. Liu, B.; Chen, Y.; St Clair, D.K. ROS and p53: A versatile partnership. Free Radic. Biol. Med. 2008, 44, 1529-1535. [CrossRef] [PubMed]

30. Wardyn, J.D.; Ponsford, A.H.; Sanderson, C.M. Dissecting molecular cross-talk between Nrf2 and NF- $k B$ response pathways. Biochem. Soc. Trans. 2015, 43, 621-626. [CrossRef]

31. Kamiya, T.; Goto, A.; Kurokawa, E.; Hara, H.; Adachi, T. Cross Talk Mechanism among EMT, ROS, and Histone Acetylation in Phorbol Ester-Treated Human Breast Cancer MCF-7 Cells. Oxid. Med. Cell. Longev. 2016, 2016, 1284372. [CrossRef]

32. Brooks, S.A.; Lomax-Browne, H.J.; Carter, T.M.; Kinch, C.E.; Hall, D.M. Molecular interactions in cancer cell metastasis. Acta Histochem. 2010, 112, 3-25. [CrossRef]

33. Yang, J. The role of reactive oxygen species in angiogenesis and preventing tissue injury after brain ischemia. Microvasc. Res. 2019, 123, 62-67. [CrossRef] [PubMed]

34. Dewhirst, M.W.; Cao, Y.; Moeller, B. Cycling hypoxia and free radicals regulate angiogenesis and radiotherapy response. Nat. Rev. Cancer 2008, 8, 425-437. [CrossRef]

35. Simon, H.U.; Haj-Yehia, A.; Levi-Schaffer, F. Role of reactive oxygen species (ROS) in apoptosis induction. Apoptosis 2000, 5, 415-418. [CrossRef] 
36. Aggarwal, V.; Tuli, H.S.; Varol, A.; Thakral, F.; Yerer, M.B.; Sak, K.; Varol, M.; Jain, A.; Khan, M.A.; Sethi, G. Role of Reactive Oxygen Species in Cancer Progression: Molecular Mechanisms and Recent Advancements. Biomolecules 2019, 9, 735. [CrossRef] [PubMed]

37. Lima, S.M.; Kehm, R.D.; Terry, M.B. Global breast cancer incidence and mortality trends by region, age-groups, and fertility patterns. EClinicalMedicine 2021, 38, 100985. [CrossRef]

38. Feng, Y.; Spezia, M.; Huang, S.; Yuan, C.; Zeng, Z.; Zhang, L.; Ji, X.; Liu, W.; Huang, B.; Luo, W.; et al. Breast cancer development and progression: Risk factors, cancer stem cells, signaling, pathways, genomics, and molecular pathogenesis. Genes Dis. 2018, 5, 77-106. [CrossRef] [PubMed]

39. Yersal, O.; Barutca, S. Biological subtypes of breast cancer: Prognostic and therapeutic implications. World J. Clin. Oncol. 2014, 5, 412-424. [CrossRef] [PubMed]

40. Burguin, A.; Diorio, C.; Durocher, F. Breast Cancer Treatments: Updates and New Challenges. J. Pers. Med. 2021, 11, 808. [CrossRef] [PubMed]

41. Ragusa, A.; Centonze, C.; Grasso, M.E.; Latronico, M.F.; Mastrangelo, P.F.; Sparascio, F.; Fanizzi, F.P.; Maffia, M. A Comparative Study of Phenols in Apulian Italian Wines. Foods 2017, 6, 24. [CrossRef] [PubMed]

42. Ragusa, A.; Centonze, C.; Grasso, M.E.; Latronico, M.F.; Mastrangelo, P.F.; Sparascio, F.; Maffia, M. HPLC Analysis of Phenols in Negroamaro and Primitivo Red Wines from Salento. Foods 2019, 8, 45. [CrossRef] [PubMed]

43. Ramírez-Garza, S.L.; Laveriano-Santos, E.P.; Marhuenda-Muñoz, M.; Storniolo, C.E.; Tresserra-Rimbau, A.; VallverdúQueralt, A.; Lamuela-Raventós, R.M. Health Effects of Resveratrol: Results from Human Intervention Trials. Nutrients 2018, 10, 1892. [CrossRef]

44. Briskey, D.; Rao, A. Trans-Resveratrol Oral Bioavailability in Humans Using LipiSperse ${ }^{\mathrm{TM}}$ Dispersion Technology. Pharmaceutics 2020, 12, 1190. [CrossRef]

45. Gambini, J.; Inglés, M.; Olaso, G.; Lopez-Grueso, R.; Bonet-Costa, V.; Gimeno-Mallench, L.; Mas-Bargues, C.; Abdelaziz, K.M.; Gomez-Cabrera, M.C.; Vina, J.; et al. Properties of Resveratrol: In Vitro and In Vivo Studies about Metabolism, Bioavailability, and Biological Effects in Animal Models and Humans. Oxid. Med. Cell. Longev. 2015, 2015, 837042. [CrossRef] [PubMed]

46. Kapetanovic, I.M.; Muzzio, M.; Huang, Z.; Thompson, T.N.; McCormick, D.L. Pharmacokinetics, oral bioavailability, and metabolic profile of resveratrol and its dimethylether analog, pterostilbene, in rats. Cancer Chemother. Pharmacol. 2011, 68, 593-601. [CrossRef] [PubMed]

47. Chimento, A.; De Amicis, F.; Sirianni, R.; Sinicropi, M.S.; Puoci, F.; Casaburi, I.; Saturnino, C.; Pezzi, V. Progress to Improve Oral Bioavailability and Beneficial Effects of Resveratrol. Int. J. Mol. Sci. 2019, 20, 1381. [CrossRef]

48. Zafar, M.S.; Quarta, A.; Marradi, M.; Ragusa, A. Recent Developments in the Reduction of Oxidative Stress through Antioxidant Polymeric Formulations. Pharmaceutics 2019, 11, 505. [CrossRef]

49. Devi, P.; Sharma, P.; Rathore, C.; Negi, P. Novel Drug Delivery Systems of Resveratrol to Bioavailability and Therapeutic Effects. In Resveratrol-Adding Life to Years, Not Adding Years to Life; Badria, F.A., Ed.; IntechOpen: London, UK, 2019. [CrossRef]

50. Oliviero, F.; Zamudio-Cuevas, Y.; Belluzzi, E.; Andretto, L.; Scanu, A.; Favero, M.; Ramonda, R.; Ravagnan, G.; López-Reyes, A.; Spinella, P.; et al. Polydatin and Resveratrol Inhibit the Inflammatory Process Induced by Urate and Pyrophosphate Crystals in THP-1 Cells. Foods 2019, 8, 560. [CrossRef] [PubMed]

51. De Maria, S.; Scognamiglio, I.; Lombardi, A.; Amodio, N.; Caraglia, M.; Cartenì, M.; Ravagnan, G.; Stiuso, P. Polydatin, a natural precursor of resveratrol, induces cell cycle arrest and differentiation of human colorectal Caco-2 cell. J. Transl. Med. 2013, 11, 264. [CrossRef] [PubMed]

52. Mikstacka, R.; Rimando, A.M.; Ignatowicz, E. Antioxidant effect of trans-resveratrol, pterostilbene, quercetin and their combinations in human erythrocytes in vitro. Plant. Foods Hum. Nutr. 2010, 65, 57-63. [CrossRef] [PubMed]

53. Du, Q.; Hu, B.; An, H.M.; Shen, K.P.; Xu, L.; Deng, S.; Wei, M.M. Synergistic anticancer effects of curcumin and resveratrol in Hepa1-6 hepatocellular carcinoma cells. Oncol. Rep. 2013, 29, 1851-1858. [CrossRef]

54. Fantacuzzi, M.; Gallorini, M.; Gambacorta, N.; Ammazzalorso, A.; Aturki, Z.; Balaha, M.; Carradori, S.; Giampietro, L.; Maccallini, C.; Cataldi, A.; et al. Design, Synthesis and Biological Evaluation of Aromatase Inhibitors Based on Sulfonates and Sulfonamides of Resveratrol. Pharmaceuticals 2021, 14, 984. [CrossRef] [PubMed]

55. Chow, H.H.; Garland, L.L.; Hsu, C.H.; Vining, D.R.; Chew, W.M.; Miller, J.A.; Perloff, M.; Crowell, J.A.; Alberts, D.S. Resveratrol modulates drug- and carcinogen-metabolizing enzymes in a healthy volunteer study. Cancer Prev. Res. 2010, 3, 1168-1175. [CrossRef]

56. Leonard, S.S.; Xia, C.; Jiang, B.H.; Stinefelt, B.; Klandorf, H.; Harris, G.K.; Shi, X. Resveratrol scavenges reactive oxygen species and effects radical-induced cellular responses. Biochem. Biophys. Res. Commun. 2003, 309, 1017-1026. [CrossRef] [PubMed]

57. Martinez, J.; Moreno, J.J. Effect of resveratrol, a natural polyphenolic compound, on reactive oxygen species and prostaglandin production. Biochem. Pharmacol. 2000, 59, 865-870. [CrossRef]

58. Tang, X.; Tang, P.; Ma, L.; Liu, L. Screening and Evaluation of Xanthine Oxidase Inhibitors from Gnetum parvifolium in China. Molecules 2019, 24, 2671. [CrossRef]

59. Ciolino, H.P.; Daschner, P.J.; Yeh, G.C. Resveratrol inhibits transcription of CYP1A1 in vitro by preventing activation of the aryl hydrocarbon receptor. Cancer Res. 1998, 58, 5707-5712. [PubMed]

60. Ciolino, H.P.; Yeh, G.C. Inhibition of aryl hydrocarbon-induced cytochrome P-450 1A1 enzyme activity and CYP1A1 expression by resveratrol. Mol. Pharmacol. 1999, 56, 760-767. 
61. Guthrie, A.R.; Chow, H.S.; Martinez, J.A. Effects of resveratrol on drug- and carcinogen-metabolizing enzymes, implications for cancer prevention. Pharmacol. Res. Perspect. 2017, 5, e00294. [CrossRef]

62. Subbaramaiah, K.; Chung, W.J.; Michaluart, P.; Telang, N.; Tanabe, T.; Inoue, H.; Jang, M.; Pezzuto, J.M.; Dannenberg, A.J. Resveratrol inhibits cyclooxygenase-2 transcription and activity in phorbol ester-treated human mammary epithelial cells. J. Biol. Chem. 1998, 273, 21875-21882. [CrossRef] [PubMed]

63. Chatterjee, M.; Das, S.; Janarthan, M.; Ramachandran, H.K.; Chatterjee, M. Role of 5-lipoxygenase in resveratrol mediated suppression of 7,12-dimethylbenz $(\alpha)$ anthracene-induced mammary carcinogenesis in rats. Eur. J. Pharmacol. 2011, 668, 99-106. [CrossRef]

64. Boo, Y.C. Human Skin Lightening Efficacy of Resveratrol and Its Analogs: From in Vitro Studies to Cosmetic Applications. Antioxidants 2019, 8, 332. [CrossRef]

65. Krajka-Kuźniak, V.; Baer-Dubowska, W. Modulation of Nrf2 and NF-kB Signaling Pathways by Naturally Occurring Compounds in Relation to Cancer Prevention and Therapy. Are Combinations Better Than Single Compounds? Int. J. Mol. Sci. 2021, 22, 8223. [CrossRef]

66. Lu, F.; Zahid, M.; Wang, C.; Saeed, M.; Cavalieri, E.L.; Rogan, E.G. Resveratrol prevents estrogen-DNA adduct formation and neoplastic transformation in MCF-10F cells. Cancer Prev. Res. 2008, 1, 135-145. [CrossRef] [PubMed]

67. Hsieh, T.C.; Lu, X.; Wang, Z.; Wu, J.M. Induction of quinone reductase NQO1 by resveratrol in human K562 cells involves the antioxidant response element ARE and is accompanied by nuclear translocation of transcription factor Nrf2. Med. Chem. 2006, 2, 275-285. [CrossRef] [PubMed]

68. Zahid, M.; Gaikwad, N.W.; Ali, M.F.; Lu, F.; Saeed, M.; Yang, L.; Rogan, E.G.; Cavalieri, E.L. Prevention of estrogen-DNA adduct formation in MCF-10F cells by resveratrol. Free Radic. Biol. Med. 2008, 45, 136-145. [CrossRef] [PubMed]

69. Inglés, M.; Gambini, J.; Miguel, M.G.; Bonet-Costa, V.; Abdelaziz, K.M.; El Alami, M.; Viña, J.; Borrás, C. PTEN mediates the antioxidant effect of resveratrol at nutritionally relevant concentrations. Biomed. Res. Int. 2014, 2014, 580852. [CrossRef]

70. Akca, H.; Demiray, A.; Aslan, M.; Acikbas, I.; Tokgun, O. Tumour suppressor PTEN enhanced enzyme activity of GPx, SOD and catalase by suppression of PI3K/AKT pathway in non-small cell lung cancer cell lines. J. Enzyme Inhib. Med. Chem. 2013, 28, 539-544. [CrossRef] [PubMed]

71. He, X.; Wang, Y.; Zhu, J.; Orloff, M.; Eng, C. Resveratrol enhances the anti-tumor activity of the mTOR inhibitor rapamycin in multiple breast cancer cell lines mainly by suppressing rapamycin-induced AKT signaling. Cancer Lett. 2011, 301, 168-176. [CrossRef] [PubMed]

72. Ma, R.; Yu, D.; Peng, Y.; Yi, H.; Wang, Y.; Cheng, T.; Shi, B.; Yang, G.; Lai, W.; Wu, X.; et al. Resveratrol induces AMPK and mTOR signaling inhibition-mediated autophagy and apoptosis in multiple myeloma cells. Acta Biochim. Biophys. Sin. 2021, 53, 775-783. [CrossRef]

73. Das, J.; Ramani, R.; Suraju, M.O. Polyphenol Compounds and PKC Signaling. Biochim. Biophys. Acta 2016, $1860,2107-2121$. [CrossRef] [PubMed]

74. Bhardwaj, A.; Sethi, G.; Vadhan-Raj, S.; Bueso-Ramos, C.; Takada, Y.; Gaur, U.; Nair, A.S.; Shishodia, S.; Aggarwal, B.B. Resveratrol inhibits proliferation, induces apoptosis, and overcomes chemoresistance through down-regulation of STAT3 and nuclear factorkappaB-regulated antiapoptotic and cell survival gene products in human multiple myeloma cells. Blood 2007, 109, $2293-2302$. [CrossRef] [PubMed]

75. Benitez, D.A.; Hermoso, M.A.; Pozo-Guisado, E.; Fernández-Salguero, P.M.; Castellón, E.A. Regulation of cell survival by resveratrol involves inhibition of NF-kappa B-regulated gene expression in prostate cancer cells. Prostate 2009, 69, 1045-1054. [CrossRef] [PubMed]

76. Sun, C.; Hu, Y.; Liu, X.; Wu, T.; Wang, Y.; He, W.; Wei, W. Resveratrol downregulates the constitutional activation of nuclear factor-kappaB in multiple myeloma cells, leading to suppression of proliferation and invasion, arrest of cell cycle, and induction of apoptosis. Cancer Genet. Cytogenet. 2006, 165, 9-19. [CrossRef]

77. Lucas, J.; Hsieh, T.C.; Halicka, H.D.; Darzynkiewicz, Z.; Wu, J.M. Upregulation of PD-L1 expression by resveratrol and piceatannol in breast and colorectal cancer cells occurs via HDAC3/p300-mediated NF-kB signaling. Int. J. Oncol. 2018, 53, 1469-1480. [CrossRef]

78. Yang, M.; Li, Z.; Tao, J.; Hu, H.; Li, Z.; Zhang, Z.; Cheng, F.; Sun, Y.; Zhang, Y.; Yang, J.; et al. Resveratrol induces PD-L1 expression through snail-driven activation of Wnt pathway in lung cancer cells. J. Cancer Res. Clin. Oncol. 2021, 147, 1101-1113. [CrossRef]

79. Verdura, S.; Cuyàs, E.; Cortada, E.; Brunet, J.; Lopez-Bonet, E.; Martin-Castillo, B.; Bosch-Barrera, J.; Encinar, J.A.; Menendez, J.A. Resveratrol targets PD-L1 glycosylation and dimerization to enhance antitumor T-cell immunity. Aging 2020, 12, 8-34. [CrossRef]

80. Sun, Y.; Zhou, Q.M.; Lu, Y.Y.; Zhang, H.; Chen, Q.L.; Zhao, M.; Su, S.B. Resveratrol Inhibits the Migration and Metastasis of MDA-MB-231 Human Breast Cancer by Reversing TGF- $\beta 1-I n d u c e d$ Epithelial-Mesenchymal Transition. Molecules 2019, 24, 1131. [CrossRef]

81. Trapp, V.; Parmakhtiar, B.; Papazian, V.; Willmott, L.; Fruehauf, J.P. Anti-angiogenic effects of resveratrol mediated by decreased VEGF and increased TSP1 expression in melanoma-endothelial cell co-culture. Angiogenesis 2010, 13, 305-315. [CrossRef]

82. Liang, Z.J.; Wan, Y.; Zhu, D.D.; Wang, M.X.; Jiang, H.M.; Huang, D.L.; Luo, L.F.; Chen, M.J.; Yang, W.P.; Li, H.M.; et al. Resveratrol Mediates the Apoptosis of Triple Negative Breast Cancer Cells by Reducing POLD1 Expression. Front. Oncol. 2021, 11, 569295. [CrossRef] 
83. Huang, C.; Ma, W.Y.; Goranson, A.; Dong, Z. Resveratrol suppresses cell transformation and induces apoptosis through a p53-dependent pathway. Carcinogenesis 1999, 20, 237-242. [CrossRef]

84. Wu, H.; Chen, L.; Zhu, F.; Han, X.; Sun, L.; Chen, K. The Cytotoxicity Effect of Resveratrol: Cell Cycle Arrest and Induced Apoptosis of Breast Cancer 4T1 Cells. Toxins 2019, 11, 731. [CrossRef]

85. Arena, A.; Romeo, M.A.; Benedetti, R.; Masuelli, L.; Bei, R.; Gilardini Montani, M.S.; Cirone, M. New Insights into Curcumin- and Resveratrol-Mediated Anti-Cancer Effects. Pharmaceuticals 2021, 14, 1068. [CrossRef]

86. Chen, Q.; Ganapathy, S.; Singh, K.P.; Shankar, S.; Srivastava, R.K. Resveratrol induces growth arrest and apoptosis through activation of FOXO transcription factors in prostate cancer cells. PLoS ONE 2010, 5, e15288. [CrossRef] [PubMed]

87. Jin, X.; Wei, Y.; Liu, Y.; Lu, X.; Ding, F.; Wang, J.; Yang, S. Resveratrol promotes sensitization to Doxorubicin by inhibiting epithelial-mesenchymal transition and modulating SIRT1/ $\beta$-catenin signaling pathway in breast cancer. Cancer Med. 2019, 8, 1246-1257. [CrossRef]

88. Yang, T.; Zhou, R.; Yu, S.; Yu, S.; Cui, Z.; Hu, P.; Liu, J.; Qiao, Q.; Zhang, J. Cytoplasmic SIRT1 inhibits cell migration and invasion by impeding epithelial-mesenchymal transition in ovarian carcinoma. Mol. Cell. Biochem. 2019, 459, 157-169. [CrossRef]

89. Chao, S.C.; Chen, Y.J.; Huang, K.H.; Kuo, K.L.; Yang, T.H.; Huang, K.Y.; Wang, C.C.; Tang, C.H.; Yang, R.S.; Liu, S.H. Induction of sirtuin-1 signaling by resveratrol induces human chondrosarcoma cell apoptosis and exhibits antitumor activity. Sci. Rep. 2017, 7, 3180. [CrossRef] [PubMed]

90. Wu, M.; Ma, L.; Xue, L.; Ye, W.; Lu, Z.; Li, X.; Jin, Y.; Qin, X.; Chen, D.; Tang, W.; et al. Resveratrol alleviates chemotherapy-induced oogonial stem cell apoptosis and ovarian aging in mice. Aging 2019, 11, 1030-1044. [CrossRef]

91. Brockmueller, A.; Sameri, S.; Liskova, A.; Zhai, K.; Varghese, E.; Samuel, S.M.; Büsselberg, D.; Kubatka, P.; Shakibaei, M. Resveratrol's Anti-Cancer Effects through the Modulation of Tumor Glucose Metabolism. Cancers 2021, 13, 188. [CrossRef]

92. Gomez, L.S.; Zancan, P.; Marcondes, M.C.; Ramos-Santos, L.; Meyer-Fernandes, J.R.; Sola-Penna, M.; Da Silva, D. Resveratrol decreases breast cancer cell viability and glucose metabolism by inhibiting 6-phosphofructo-1-kinase. Biochimie 2013, 95, 13361343. [CrossRef]

93. Qasem, R.J. The estrogenic activity of resveratrol: A comprehensive review of in vitro and in vivo evidence and the potential for endocrine disruption. Crit. Rev. Toxicol. 2020, 50, 439-462. [CrossRef]

94. Cavalieri, E.; Rogan, E. The 3,4-Quinones of Estrone and Estradiol Are the Initiators of Cancer whereas Resveratrol and N-acetylcysteine Are the Preventers. Int. J. Mol. Sci. 2021, 22, 8238. [CrossRef] [PubMed]

95. van der Zanden, S.Y.; Qiao, X.; Neefjes, J. New insights into the activities and toxicities of the old anticancer drug doxorubicin. FEBS J. 2020, in press. [CrossRef] [PubMed]

96. Tatlidede, E.; Sehirli, O.; Velioğlu-Oğünc, A.; Cetinel, S.; Yeğen, B.C.; Yarat, A.; Süleymanoğlu, S.; Sener, G. Resveratrol treatment protects against doxorubicin-induced cardiotoxicity by alleviating oxidative damage. Free Radic. Res. 2009, 43, 195-205. [CrossRef] [PubMed]

97. Gu, J.; Hu, W.; Song, Z.P.; Chen, Y.G.; Zhang, D.D.; Wang, C.Q. Resveratrol-induced autophagy promotes survival and attenuates doxorubicin-induced cardiotoxicity. Int. Immunopharmacol. 2016, 32, 1-7. [CrossRef]

98. Ruan, Y.; Dong, C.; Patel, J.; Duan, C.; Wang, X.; Wu, X.; Cao, Y.; Pu, L.; Lu, D.; Shen, T.; et al. SIRT1 suppresses doxorubicininduced cardiotoxicity by regulating the oxidative stress and p38MAPK pathways. Cell. Physiol. Biochem. 2015, 35, 1116-1124. [CrossRef]

99. Komorowska, D.; Gajewska, A.; Hikisz, P.; Bartosz, G.; Rodacka, A. Comparison of the Effects of Resveratrol and Its Derivatives on the Radiation Response of MCF-7 Breast Cancer Cells. Int. J. Mol. Sci. 2021, 22, 9511. [CrossRef] [PubMed]

100. Kensler, T.W.; Wakabayashi, N. Nrf2: Friend or foe for chemoprevention? Carcinogenesis 2010, 31, 90-99. [CrossRef] [PubMed]

101. Singh, B.; Bhat, N.K.; Bhat, H.K. Induction of NAD $(\mathrm{P}) \mathrm{H}$-quinone oxidoreductase 1 by antioxidants in female ACI rats is associated with decrease in oxidative DNA damage and inhibition of estrogen-induced breast cancer. Carcinogenesis 2012, 33, 156-163. [CrossRef]

102. Dawling, S.; Roodi, N.; Parl, F.F. Methoxyestrogens exert feedback inhibition on cytochrome P450 1A1 and 1B1. Cancer Res. 2003, 63, 3127-3132. [PubMed]

103. Cooper, A.J.L.; Hanigan, M.H. Metabolism of Glutathione S-Conjugates: Multiple Pathways. In Comprehensive Toxicology, 3rd ed.; McQueen, C.A., Ed.; Elsevier: Oxford, UK, 2018; pp. 363-406.

104. Yasuda, M.T.; Sakakibara, H.; Shimoi, K. Estrogen- and stress-induced DNA damage in breast cancer and chemoprevention with dietary flavonoid. Genes Environ. 2017, 39, 10. [CrossRef]

105. Miricescu, D.; Totan, A.; Stanescu, S., II; Badoiu, S.C.; Stefani, C.; Greabu, M. PI3K/AKT/mTOR Signaling Pathway in Breast Cancer: From Molecular Landscape to Clinical Aspects. Int. J. Mol. Sci. 2020, 22, 173. [CrossRef] [PubMed]

106. Paplomata, E.; O'Regan, R. The PI3K/AKT/mTOR pathway in breast cancer: Targets, trials and biomarkers. Ther. Adv. Med. Oncol. 2014, 6, 154-166. [CrossRef]

107. Xie, Y.; Shi, X.; Sheng, K.; Han, G.; Li, W.; Zhao, Q.; Jiang, B.; Feng, J.; Li, J.; Gu, Y. PI3K/Akt signaling transduction pathway, erythropoiesis and glycolysis in hypoxia. Mol. Med. Rep. 2019, 19, 783-791. [CrossRef]

108. Chen, C.-Y.; Chen, J.; He, L.; Stiles, B.L. PTEN: Tumor Suppressor and Metabolic Regulator. Front. Endocrinol. 2018, 9, 338. [CrossRef]

109. Zou, Z.; Tao, T.; Li, H.; Zhu, X. mTOR signaling pathway and mTOR inhibitors in cancer: Progress and challenges. Cell Biosci. 2020, 10, 31. [CrossRef] 
110. Tong, C.W.S.; Wu, M.; Cho, W.C.S.; To, K.K.W. Recent Advances in the Treatment of Breast Cancer. Front. Oncol. 2018, 8, 227. [CrossRef]

111. Zuckerman, V.; Wolyniec, K.; Sionov, R.V.; Haupt, S.; Haupt, Y. Tumour suppression by p53: The importance of apoptosis and cellular senescence. J. Pathol. 2009, 219, 3-15. [CrossRef] [PubMed]

112. Fu, Z.; Tindall, D.J. FOXOs, cancer and regulation of apoptosis. Oncogene 2008, 27, 2312-2319. [CrossRef]

113. Vander Heiden, M.G.; Cantley, L.C.; Thompson, C.B. Understanding the Warburg effect: The metabolic requirements of cell proliferation. Science 2009, 324, 1029-1033. [CrossRef] [PubMed]

114. Al-jubori, A.A.; Sulaiman, G.M.; Tawfeeq, A.T.; Mohammed, H.A.; Khan, R.A.; Mohammed, S.A.A. Layer-by-Layer Nanoparticles of Tamoxifen and Resveratrol for Dual Drug Delivery System and Potential Triple-Negative Breast Cancer Treatment. Pharmaceutics 2021, 13, 1098. [CrossRef]

115. Yang, M.D.; Sun, Y.; Zhou, W.J.; Xie, X.Z.; Zhou, Q.M.; Lu, Y.Y.; Su, S.B. Resveratrol Enhances Inhibition Effects of Cisplatin on Cell Migration and Invasion and Tumor Growth in Breast Cancer MDA-MB-231 Cell Models In Vivo and In Vitro. Molecules 2021, 26, 2204. [CrossRef] 